\title{
The Cytotoxicity Study of Lantana camara Linn Essential Oil on HeLa Cancer Cells Line
}

\author{
Suryati ${ }^{1, *}$, Dira Hefni ${ }^{2}$, Fatma Sri Wahyuni ${ }^{2}$, Dachriyanus ${ }^{2}$
}

Suryati ${ }^{1, *}$, Dira Hefni ${ }^{2}$, Fatma Sri Wahyuni $^{2}$, Dachriyanus ${ }^{2}$

'Department of Chemistry, Universitas Andalas, Kampus Limau Manis, Padang, West Sumatra 25163, INDONESIA. ${ }^{2}$ Faculty of Pharmacy, Universitas Andalas, Kampus Limau Manis, Padang, West Sumatra 25163, INDONESIA.

\section{Correspondence}

Suryati

Department of Chemistry, Faculty of Mathematics and Natural Sciences, Universitas Andalas, Kampus Limau Manis, Padang, West Sumatra 25163, INDONESIA.

Phone no: +6281363190221;

E-mail: suryati@sci.unand.ac.id

History

- Submission Date: 24-08-2021;

- Review completed: 06-09-2021;

- Accepted Date: 14-09-2021.

DOI : 10.5530/pj.2021.13.190

Article Available online

http://www.phcogj.com/v13/i6

Copyright

(C) 2021 Phcogj.Com. This is an openaccess article distributed under the terms of the Creative Commons Attribution 4.0 International license.

\begin{abstract}
Lantana camara Linn (Verbenaceae) is a natural plant that thrives in tropical climates and is relatively easy to cultivate. In Indonesia, this plant is still often considered as a weed. When held, the unpleasant smell and sticky hand make people dislike this plant even though the flowers are diverse. The essential oil was extracted from the leaves of $L$. camara by hydrodistillation. This study aimed to see how cytotoxic $L$. camara essential oil was against HeLa carcinoma cells. This research aimed to discover if $L$. camara essential oil was cytotoxic to HeLa cancer cells. The GC-MS investigation of an essential oil recognized ten compounds; two main constituents of the oil were Caryophyllene (27.65\%) and Germacrene D $(23.01 \%)$. The essential oil showed cytotoxicity on HeLa cervical cancer cell lines. The cytotoxic effect of oil was determined using MTT, IC ${ }_{50}$ values were $44.86 \mu \mathrm{g} / \mathrm{mL} \pm 0.07$.

Key word: Cytotoxicity, HeLa, Hydrodistillation, Lantana camara, Cervical cancer
\end{abstract}

\section{INTRODUCTION}

Lantana camara Linn. (Verbenaceae) is a tropical American native that has been used as an ornamental and hedge plant in many other nations. As an invasive noxious weed, this plant has spread swiftly and been naturalized in more than 60 countries. Because native plant species' regeneration processes are interrupted, L. camara usually creates dense monospecies stands. ${ }^{1}$ The plant L. camara possesses various medicinal values and has different ethnomedicinal uses. Antioxidants, antiprotozoal, antimicrobials, and insecticides have been discovered in L. camara leaves and flower extracts. ${ }^{2,3}$ The plant essential oil shows effectiveness towards various microbial strains indicating its antimicrobial properties. ${ }^{4,5}$

Essential oils extracted from plants play an essential role in medicine, in addition to their tremendous value in the cosmetics and nutraceutical industries. ${ }^{6}$ The use of essential oils of aromatic plants for food and medical purposes has been a focus of research in health sciences due to their varied biological features such as antibacterial, analgesic, anti-inflammatory, antiparasitic, antioxidant, and antitumoral activity. Many aromatic therapeutic plant species have been the subject of studies examining the impact of time on the chemical makeup of essential oils. This occurs because the time it takes to collect the materials is an important factor to consider when dealing with essential oil production. ${ }^{8}$

Cervical cancer is a primary cancer of the cervix whose mechanism begins with epithelial metaplasia in the transformation zone, namely the meeting of the vaginal mucosa with the cervical canal. This cancer, which affects women between the ages of 35 and 55, is the world's second most common type of cancer in women. ${ }^{9}$ The main cause of cervical precancer and cancer is persistent infection with one or more of the high-risk oncogenic types of human papillomavirus (HPV). HPV causes various modifications in the epithelial cells of the cervix's transformation zone, disrupting their normal functioning. ${ }^{10}$ Cervical cancer prevention and the impact of screening programs on cervical cancerrelated mortality have garnered major attention in rich countries, in contrast to the modest effort found in most low- and middle-income countries. ${ }^{11}$ Garcinia cowa, for example, has been studied for its anticancer activity on the HeLa cell line. ${ }^{12}$ This species show cytotoxicity activities on several cancer cell lines..$^{13,14-18}$

The purpose of this study was to learn more about the chemical makeup of L. camara essential oils obtained from Padang using GC-MS and to assess theirs in vitro cytotoxicity activities on HeLa cancer cells.

\section{MATERIALS AND METHODS}

\section{Extraction of oils}

L. Camara leaves were taken near the Universitas Andalas campus in Limau Manis, Padang. Dr. Nurainas identified the voucher specimens in the Herbarium Universitas Andalas, Indonesia by Number 472/K-ID/ANDA/XII/2017. The leaves of the plants that have been collected are then cleaned and cut into pieces. These pieces are then dried until dry leaves are obtained. The essential oil is isolated by distillation of water. A sample of $\pm 1 \mathrm{~kg}$ of leaves is put into a distillation flask as a container for the sample in a series of water distillation devices. Then the appliance is heated for 4 hours, starting from the first drop. The essential oil obtained after distillation is separated from the water layer using a separating funnel and collected into a brown glass bottle covered with aluminum foil. The essential oil that has been separated from water is drained from the water, which is still present in the essential oil using anhydrous sodium sulfate. The purpose of this study was to learn more about the chemical makeup of $L$. camara essential oils obtained from Padang using GC-MS and to assess theirs in vitro cytotoxicity activities on HeLa cancer cells. 


\section{Determination of the chemical contents of essential oil}

Chemical compounds in the essential oil of leaves sample were analyzed using a GC-MS tool with the following conditions: Instrument: GC Agilent $^{\circ}$ 7890A, Detector: MS Agilent ${ }^{\oplus}$ 5975C, Column: HP-5ms $\left(\right.$ Agilent $\left.{ }^{\otimes}\right)$, diameter $0.25 \mathrm{~mm}$, thick $0.25 \mu \mathrm{m}$, length $30 \mathrm{~m}$. Flow rate of gas: $1 \mathrm{ml} / \mathrm{min}$. Temperature in the column: $50-300{ }^{\circ} \mathrm{C}$ (temperature constant $50^{\circ} \mathrm{C}$ for 2 minutes, the temperature is increased to $80^{\circ} \mathrm{C}$ in $2^{\circ} \mathrm{C} /$ minute increments, then increased to $150^{\circ} \mathrm{C}$ in $5^{\circ} \mathrm{C} / \mathrm{min}$ increments, then increased to $200^{\circ} \mathrm{C}$ in $10^{\circ} \mathrm{C} /$ minute increments and then increased to $300^{\circ} \mathrm{C}$ with increase of $20^{\circ} \mathrm{C} / \mathrm{min}$, at $300^{\circ} \mathrm{C}$ maintained constant for 5 minutes), Injector temperature: $250{ }^{\circ} \mathrm{C}$ (constant), Detector temperature: $270{ }^{\circ} \mathrm{C}$, energy $1.25 \mathrm{kV}$. Carrier gas: Helium Injection volume: $0.1 \mu \mathrm{l}$ Column pressure: $70 \mathrm{kPa}$.

\section{DETERMINATION OF CYTOTOXICITY}

\section{Cell Culture}

In RPMI media having $100 \mathrm{~g} / \mathrm{mL}$ streptomycin, $100 \mathrm{IU} / \mathrm{mL}$ penicillin and $10 \% \mathrm{v} / \mathrm{v}$ FBS, under humidified 5 percent $\mathrm{CO}_{2}$ incubator, cells were cultivated $\left(37^{\circ} \mathrm{C}\right), \mathrm{HeLa}$ cells were grown. The cells were extracted for 5-10 minutes with a $1 \mathrm{~mL}$ trypsin-EDTA solution after they had reached 80 percent confluency. Under an inverted microscope, the cells were examined, and $3 \mathrm{~mL}$ of complete growth media was added to the flask. In a new flask with fresh media, $0.5-1 \times 10^{6}$ cells were subcultured.

\section{Viability Assay}

The vitality of the cells was determined using the MTT test. HeLa cells $\left(2 \times 10^{3}\right.$ cells/well $)$ were seeded into 96-well culture plates and incubated at $37^{\circ} \mathrm{C}$ overnight in $5 \% \mathrm{CO}_{2}$. The cells were given an essential oil treatment for 48 hours. The wells were then filled with $100 \mathrm{~mL}$ MTT $(0.5 \mathrm{mg} / \mathrm{mL})$ and incubated at $37^{\circ} \mathrm{C}$ for four hours. MTT was taken off the plate. Each well received $100 \mathrm{~mL}$ of DMSO. The Microplate Reader was used to measure the absorbance at $550 \mathrm{~nm}$.

\section{RESULTS AND DISCUSSION}

Essential oils have a wide range of chemical compositions based on the type of plant, climate, growing region, season, type of soil, extraction method, and plant part used. Therefore, in this research, the leaves was subjected to hydrodistillation to yield $0.0781 \%(\mathrm{w} / \mathrm{w})$. The ten primary ingredients of the essential oil discovered by GC-MS are listed in Table 1. Caryophyllene (27.65\%) and Germacrene D (23.01\%) had the highest mean content values, followed by Cyclodecadiene (23.01\%).

Caryophyllene is a bicyclic sesquiterpene that is found in plants. This chemical has potent anticancer properties, inhibiting the growth and multiplication of a variety of cancer cells. Caryophyllene enhances the efficacy of traditional drugs by increasing their concentrations inside cells. Caryophyllene is a phytocannabinoid that binds to cannabinoid receptors with a high affinity. Caryophyllene has been demonstrated

Table 1: Lists the chemicals found in L. Camara essential oil.

\begin{tabular}{lcc}
\hline Chemicals & Amount (\%) & Retention Time (Min) \\
\hline a-Pinene & 04.04 & 3.32 \\
o-Cymene & 05.38 & 4.93 \\
Cyclohexane & 0.270138889 & 19.84 \\
Caryophyllene & 27.65 & 21.22 \\
Humulene & 0.277083333 & 22.59 \\
Germacrene D & 23.01 & 23.96 \\
Naphthalene & 0.264583333 & 24.45 \\
Hexahydronaphthalene & 0.223611111 & 25.69 \\
Cyclodecadiene & 11.26 & 27.04 \\
Patchouli alcohol & 06.15 & 30.56
\end{tabular}

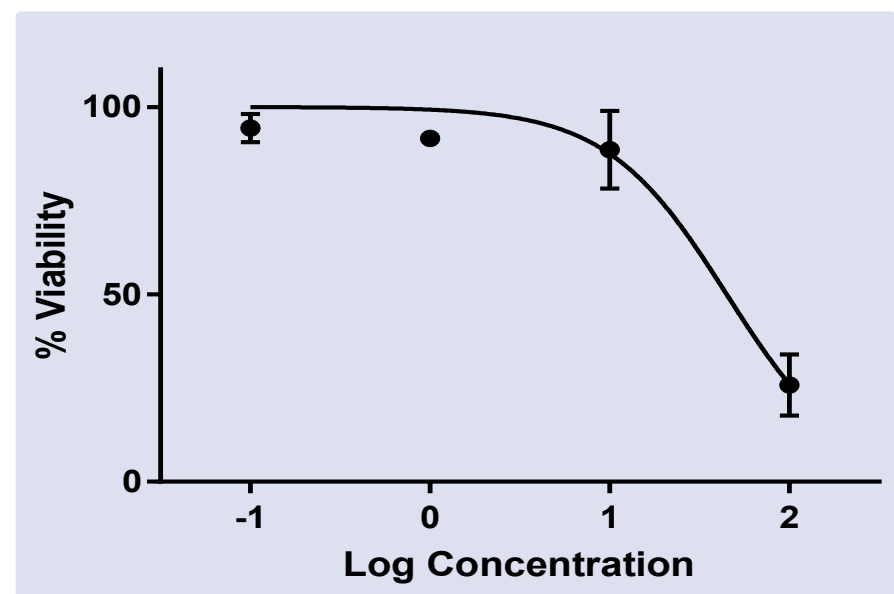

Figure 1: Essential oil of $L$. camara inhibits the viability of HeLa cancer cells. The averages \pm standard deviations of three independent experiments make up the data.

to affect several important cancer pathways, including the mitogenactivated protein kinase pathway. (MAPK), PI3K/AKT/mTOR/S6KI, and STAT3 pathways. ${ }^{19}$

A brine shrimp was used to test the essential oil, which contains germacrene $\mathrm{D}$, as found in Mugwort (Artemisia vulgaris L.) plants. Germacrene D was discovered to be the first major ingredient in the oils studied. ${ }^{20}$

To examine the effect of $L$. camara essential oil as an anticancer agent, HeLa cells were treated with essential oil $(0-100 \mathrm{~g} / \mathrm{mL})$ for 48 hours and cell viability was determined using the MTT test. The $\mathrm{IC}_{50}$ is derived using a plot of cell viability (percentage) vs essential oil concentration. The treatments were tested at varied concentrations in the cell viability assay. HeLa cancer cells were decreased in a dose-dependent manner by essential oil with $\mathrm{IC}_{50}$. The $\mathrm{IC}_{50}$ value was $44.86 \mathrm{~g} / \mathrm{mL} \pm 0.07$ after 48 hours of incubation (Figure 1).

\section{CONCLUSION}

This study concludes that essential oils of $L$. camara contain the main chemical are Caryophyllene and Germacrene D and can be proposed as drug candidate as anticancer agent.

\section{ACKNOWLEDGEMENTS}

This research is funded by the The ministry of Education and Culture, through LPPM Unand in accordance with the research contract No LPPM: T/5/UN.16.17/PP.KO.PDU.KRP2GB-Unand//LPPM/2021.

\section{CONTRIBUTIONS FROM THE AUTHOR}

All authors contributed significantly to the conceptualization and design, data collection, data analysis, and data interpretation; participated in the drafting of the article or critically revised it for important intellectual content; agreed to submit the article to the current journal; gave final approval of the version to be published; and agreed to be responsible for all aspects of the work.

\section{INTEREST CONFLICTS}

There are no financial or other conflicts of interest among the authors of this study.

\section{ETHICAL APPROVALS}

There are no animal or human subjects in this study. 


\section{NOTE FROM THE EDITOR}

This publication remains neutral in terms of jurisdictional claims in published institutional affiliation.

\section{REFERENCES}

1. Kato-Noguchi H, Kurniadie D. Allelopathy of lantana camara as an invasive plant. Plants. 2021; 10(5):1028

2. Patil SP, Kumbhar ST. Evaluation of terpene-rich extract of Lantana camara L. leaves for antimicrobial activity against mycobacteria using Resazurin Microtiter Assay (REMA). Beni-Suef Univ J Basic Appl Sci, 2018; 7(4):511-514.

3. 3.Sousa EO, Costa JGM. Genus Lantana: Chemical aspects and biological activities. Rev Bras Farmacogn, 2012; 22(5): 1155-1180,

4. Deena MJ, Thoppil JE. Antimicrobial activity of the essential oil of Lantana camara. Fitoterapia, 2000; 71(4):453-455.

5. Munda S, Dutta S, Pandey SK, Sarma N, Lal M. Antimicrobial Activity of Essential Oils of Medicinal and Aromatic Plants of the North East India: A Biodiversity Hot Spot. J Essent Oil-Bearing Plants, 2019; 22(1):105-119.

6. Jaradat N, Al-Maharik N, Abdallah S, Shawahna R, Mousa A, Qtishat A. Nepeta curviflora essential oil: Phytochemical composition, antioxidant, anti-proliferative and anti-migratory efficacy against cervical cancer cells, and $\alpha$-glucosidase, $\alpha$-amylase and porcine pancreatic lipase inhibitory activities. Ind Crops Prod, 2020; 158: 112946.

7. Santos PASR, Avanço GB, Nerilo SB, Marcelino RIA, Janeiro V, Valadares MC, Machinski M. Assessment of cytotoxic activity of rosemary (Rosmarinus officinalis L.), Turmeric (Curcuma longa L.), and Ginger (Zingiber officinale R.) essential oils in cervical cancer cells (HeLa). Sci World J, 2016; 9273078:1-8

8. Sousa EO, Colares AV, Rodrigues FFG, Campos AR, Lima SG, Costa JGM. Effect of collection time on essential oil composition of Lantana camara Linn (Verbenaceae) growing in Brazil Northeastern. Rec Nat Prod, 2010; 4(1):31-37.

9. Stelzle D, Tanaka LF, Lee KK, Ibrahim KA, Baussano I, Shah ASV McAllister DA, Gottlieb SL, Klug SJ, Winkler AS, Bray F, Baggaley R, Clifford GM, Broutet N, Dalal S. Estimates of the global burden of cervical cancer associated with HIV. Lancet Glob Heal, 2021; 9(2):e161-e169.
10. World Health Organization. 2006. Comprehensive Cervical Cancer Control. A guide to essential practice. WHO Libr. Cat. Data, New York.

11. American Cancer Society. 2018. Global Cancer Facts \& Figures, 4th Edition. New York: ACS.

12. Wahyuni FS, Febria S, Arisanty D. Apoptosis induction of cervical carcinoma HeLa cells line by dichloromethane fraction of the rinds of Garcinia cowa roxb. Pharmacogn J, 2017; 9(4):475-478.

13. Hefni D, Dachriyanus, Wahyuni FS, Yerizel, E., Arisanty, D., Yusra, L.N., Cowanin, a Cytotoxic Xanthone from Asam Kandis (Garcinia cowa, Roxb.) Reduced Cell Migration and Induced Cell Cycle Arrest on T47D Human Cancer Cell. Int J Adv Sci Eng Inf Technol, 2020; 10(5):2164-2169

14. Wahyuni FS, Hui LS, Stanslas J, Lajis NH, Dachriyanus. Tetraprenyltoluquinone, an anticancer compound from Garcinia cowa Roxb induce cell cycle arrest on $\mathrm{H} 460$ non small lung cancer cell line. Int J Pharm Sci Rev Res, 2015a; 32(2):166-168

15. Wahyuni FS, Shaari K, Stanslas J, Lajis NH, Hamidi D. Cytotoxic compounds from the leaves of Garcinia cowa Roxb. J Appl Pharm Sci, 2015b; 5(2):005-011.

16. Wahyuni, F.S., Stanslas, J., Lajis, N.H., Dachriyanus. Cytotoxicity studies of tetraprelyltoluquinone, a prenilated hydroquinone from Garcina cowa Roxb on H-460, MCF-7 and DU-145. Int J Pharm Pharm Sci, 2015c; 7(3): 60-63.

17. Wahyuni FS, Triastuti DH, Arifin H. Cytotoxicity study of ethanol extract of the leaves of asam kandis (Garcinia cowa Roxb.) on T47D breast cancer cell line. Pharmacogn J, 2015d; 7(6);369-371.

18. Wahyuni FS, Shaari K, Stanslas J, Lajis NH, Hamidi D. Cytotoxic properties and complete nuclear magnetic resonance assignment of isolated xanthones from the root of Garcinia cowa Roxb. Pharmacogn Mag, 2016; 12(suppl 1):S52-S56.

19. Fidyt K, Fiedorowicz A, Strzadała L, Szumny A. $\beta$-caryophyllene and $\beta$-caryophyllene oxide-natural compounds of anticancer and analgesic properties. Cancer Med, 2016; 5(10):3007-3017.

20. Judžentienè A, Būdienè J. Mugwort (Artemisia vulgaris L.) essential oils rich in germacrene $D$, and their toxic activity. J Essent Oil Res, 2021;33:256-264.

\section{GRAPHICAL ABSTRACT}

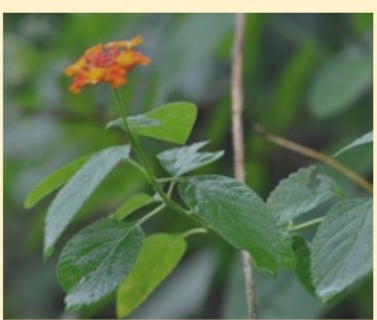

Leaves of Lantana camara Linn
Determination of the chemical contents of essential oil
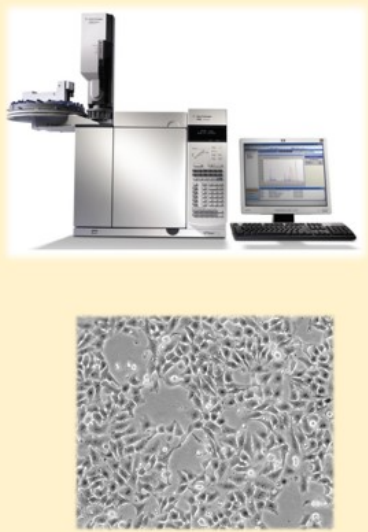

Cytotoxic to HeLa Cancer cells 


\section{ABOUT AUTHORS}

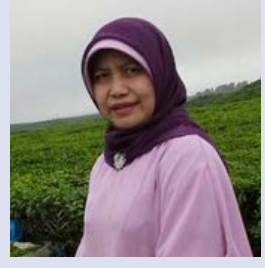

Dr. Suryati, MSi is a lecture at Department of Chemistry, the Faculty of Mathematics and Natural Sciences, Andalas University. She got her doctorate degree in natural products chemistry in 2011. Her research is focusing on isolation active compound from natural product.

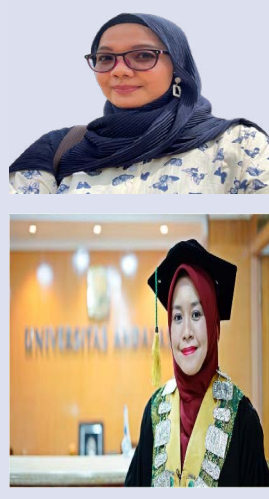

Dr. Dira Hefni, MSc, Apt is a lecture at the Faculty of Pharmacy, Andalas University. She got her PhD in Biomedical Science 2021. She work with cytotoxic activity of Garcinia cowa plant.

Prof. Dr. Fatma Sri Wahyuni, Apt. She is a lecturer at the Faculty of Pharmacy, Andalas University. Got her undergraduate degrees from Andalas University in 1998 and finished her $\mathrm{PhD}$ from University Putra Malaysia in 2010. Her research is focusing on pharmacolgycal activity studies of Sumatran Plants.

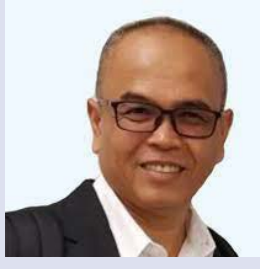

Prof. Dr. Dachriyanus, Apt. He is as a lecturer at the Faculty of Pharmacy, Andalas University. He got his PhD degree at Department of chemisty, University of Western Australia in 2000. His research interest in conducting research on anticancer, antimicrobial active compounds from natural ingredients

Cite this article: Suryati, Hefni D, Wahyuni FS, Dachriyanus. The Cytotoxicity Study of Lantana camara Linn Essential Oil on HeLa Cancer Cells Line. Pharmacogn J. 2021;13(6): 1498-1501. 